\title{
It Doesn't Have to Protest: A Review of Black or Right: Anti/Racist Campus Rhetorics
}

\author{
Shenita Denson
}

Black PhD student. Servant Leader. Social Scientist. Lecturer. A Creative. I am much more than that but \#WordCountMatters. Born and raised in the American south by amazing military parents, I quickly developed a love for diverse cultures, hugs, the arts, storytelling + food for the soul. My research focuses on the stories we hear and tell (and those we wish we heard or told) and how they impact our identities, relationships, and our health/well-being (Koenig-Kellas, 2016). I am committed to eradicating the injustices against Blacks through my belief that communicating and voice is power. To learn more, www.shenitadenson.com.

\begin{abstract}
[To predominantly white institutions:] Whose responsibility is it to make our Black community feel like their lives matter here, and what are we purposefully and creatively doing about it [every day] to live up to it?
\end{abstract}

Reflecting critically on my own intimate experiences as a Black doctoral student, college lecturer, and former student affairs professional in predominantly white spaces, I share an insightful review of Louis M. Maraj's (2020) riveting new book, Black or Right: Anti/Racist Campus Rhetorics. Based on the title, I initially expected Black or Right to be some sort of a guidebook to help campuses learn how to refrain from using racist language in their marketing, programming, classrooms, and ways of interacting with campus constituents and community partners. I speculated that it would teach these same folx how to make Black faculty, staff, and students feel welcomed and equal instead of anxious and hyperaware. I thought about the white colleagues [and students] I could pass this text on to, with the accompanying note, "You might like this!," which really means, "You need this." Sigh. While Black or Right is not a guidebook on how to eliminate racist language on college campuses or an explicit outline for how to embrace the Black members on them, it is a beautiful piece of choreographed words that illustrates, examines, and disrupts how decolonized ways of writing, storytelling, and ways of being, teaching, and communicating on college campuses confronts, strategizes, calls out/in, and proclaims notions of Blackness in anti-Black spaces. I argue that this type of work is far more important than a Black person writing another book to teach white people how to talk to and treat us. Black or Right pays homage to and educates readers on the Black academy's social justice pioneers, whose trailblazing paths and research encourage us to keep running in this race and reminds us we are dynamic. Courageously accepting the baton to complete the next leg, Maraj empowers and pushes us to run alongside him through his creative ability to discuss these topics through literary events, discussions, and assignments he has created in his own safe space, in his classroom. Brother Maraj, thank you for bringing your whole self, multiple identities, and diverse lived experiences to this text. In the spirit of your mother who allowed you to leave the islands to come to the US for greater opportunities - this book is a manifestation of her knowing your worth. Thank you for writing this fascinating piece that reminds us to never forget our worth, to demand our respect, and for educating and engaging all people in this necessary dialogue. Black is right. Black is right. Black is right. But Black folx are always protesting. Dear Brothers and Sisters, never forget: We always mattered.

\section{Keywords}

campus rhetoric, Black tokenization, institutional racism, counterstory, Blackness 
t's another start of a semester and as I enter my assigned classroom with my locs tied in an African-printed headwrap, large gold hoop earrings, and my favorite shirt that reads "Positive Vibes Only," I notice my predominately white students awkwardly tracing my steps, silently, with hesitation and doubt, questioning who I am. Their curiosity [or judgement] is deafening to my ears. It's a familiar feeling of wondering how my Blackness will be perceived as I first enter a new space, especially in a role that commands leadership. I return to my eight-year-old self who lay on the couch every day at 4 o'clock to witness the gregarious Ms. Oprah Winfrey walk on stage surrounded by a standing ovation. In awe, I observed how eloquently she connected with people from diverse backgrounds, employing transparency, dialogue, and heart. What intrigued me most was not that she was Black like me but that she had the ability to ask the right questions and reveal intimate details about her life, that using her voice empowered others to unsilence theirs. After viewing dozens of episodes full of transformative conversations, I learned that when done right, communicating can be life changing. I was convinced that if I also mastered being able to guide challenging conversations while creating brave spaces for them to take place, then [Black] people like me really mattered. This is where my passion for communication began; I plant its seeds wherever I go, anticipating its bloom. As I introduce myself to my new students and avow that my class is sacred, their anxious eyes turn to warmth, and they exhale. Subsequently, I inhale divine affirmation that this is another opportunity for me to be more of what the world needs and in the front of the classroom - a place where many of my ancestors never stood - is where I am supposed to be.

As a former student affairs professional who focused on [what now seem like buzz words] diversity, equity, and inclusion work, and as a current college lecturer, doctoral student, and interpersonal communication scholar, I was immediately captivated by the title of Louis Maraj's book, Black or Right: Anti/Racist Campus Rhetorics (2020). In full transparency, I was a bit hesitant to dive in after discovering he has an English, writing, and Black feminist studies academic background. While I am moderately versed in these topics, some more than others, I am not an expert. Therefore, I wasn't sure if this text would keep my interest. When I saw "writing," I may or may not have been triggered. Consequently, I thought of the many Black folx who have been traumatized in the classroom due to the horrific ways our language and writing style have been marked up and scratched out with the dreaded red pen. Maraj candidly relates,

In the freshman English classroom, I learn about the (white US) middle (?) class "struggle" as we read Arthur Miller's Death of a Salesman. My white woman instructor dresses like the kids on Freaks and Geeks - a TV show a subsequent white roommate exposes me to. . . Shakespeare's
Othello features the only character of color on the syllabus - one mediated through the author's sixteenth/ seventeenth-century imagination through discourses of antiBlackness. I receive a C- on my first paper - after three pages, a slash across every one after with the message that the instructor stopped reading there. (p. 4)

Luckily, my fears of reading this text were quickly diminished when I discovered the author was Black. In that discovery, however, I also noticed the unpleasant feelings that rose to the surface, as if I wasn't rooting for the home team when I always want us to win. Let me explain. Since starting my doctoral journey, l've found myself approaching texts written by Black scholars with a bit of judgement. I ask, "Will this come off as another inner protest piece with heavy jargon and incomprehensible ideas to prove this Black author is smart and belongs here too? Sis/Brother, who are you really writing this for - us or them?" This judgement is hard to confess and a bit hypocritical of me, considering I have been guilty of writing for them too. Y'all, being Black can be so exhaustingly performative, and the white academy has made us this way. My unintentional questioning of Black scholars reflects the master narrative of the white academy that has historically questioned and still questions our voice, credentials, role, and place-that still marks up our work with red slashes. I believe this speaks to why so many of us suffer from imposter syndrome. It's not our doubts, it's the white systems and spaces we occupy that doubt us, and thus we [unconsciously] start to believe them.

I also made note of Maraj's academic background because I intentionally take note of an author's discipline to see how readers from different contexts will be able to relate. I approach my own writing, research, and praxis similarly. Specifically, if my non-college-educated parents cannot understand my work, then I recraft it; this is important to me. If I can't understand with my multiple degrees and academic experiences, I'm concerned that other Black folx without these things can't. I share this because as Black scholars, if we are truly invested in creating systems of change, it should be our duty to ensure that those who look like us in/outside of the academy can understand our work.

Based on the title, I initially expected Black or Right to be some sort of a guidebook to help campuses learn how to refrain from using racist language in their marketing, programming, classrooms, and ways of interacting with campus constituents and community partners. I speculated that it would teach these same folx how to make Black faculty, staff, and students feel welcomed and equal instead of anxious and hyperaware, like my usual first-day-of-class experiences I share in the opening of this review. I instantly thought about the white colleagues [and students] I could pass this text on to, with the accompanying note, "You might like this!," which really means, "You need this." White folx need as many antiracist resources as possible, and I applaud texts like How to Be an Antiracist (Kendi, 2019) that are making these difficult conversations more intentional and digestible for non-Black folx. 
While Black or Right is not a guidebook on how to eliminate racist language on college campuses or an explicit outline for how to embrace the Black members on them, I was pleasantly surprised and released a calming sigh when I discovered it is a beautiful piece of choreographed words that illustrates, examines, and disrupts how decolonized ways of writing, storytelling, and ways of being, teaching, and communicating confront, strategize, call out/in, and proclaim notions of Blackness in anti-Black spaces. I argue that this type of work is far more important than a Black person writing another book to teach white people how to talk to and treat us. Like many of the recently hired Black folx in "diversity and inclusion" roles, who were conveniently brought on only after companies felt the need (or were forced) to take a public stand regarding the police brutality protests across the nation last summer, I counterprotest that this work is not our [Black people] fatiguing responsibility. We should be relevant beyond trying to fix the problems white folks have created. We have value beyond meeting an institution's diversity quota or being plastered on the company's website to prove it is diverse. You will never hear me say "Black lives matter" because we always mattered. I don't need to, nor will I ever protest that; that's white folks' battle. Maraj further illustrates this notion in the beginning of the text when detailing how his former institution frequently tokenized and exploited his Blackness.

On the glossy cover of the summer 2009 issue of Liberal Arts College's (2009) Liberal Arts College Magazine, a publication by its Division of Institutional Advancement (emphasis mine) my image stands out like a Black thumb. . It is telling that the magazine chooses to present my image and narrative first. That choice, along with my tokenization as exceptional and exotic, and positioning with/in the histories of the institution's name, demonstrates the deep ecological rhetorics of white capitalist heteropatriarchal educational institutions. . .my image delivers to alumni, parents, and fellow students a notion of inclusivity via race and citizenship status. . and the accounts of my "success" pats the white institution, its appendages, and contributors on the back. The institution, indeed, advances. (pp. 24-26)

Black or Right seeks to achieve several interrelated goals. One of the primary goals is to investigate Blackness in white educational spaces and the implicit and explicit messages used to describe it. Maraj aims to make sense of how Black identity functions in the highly politicized, controversial era of "post- Ferguson"/\#BlackLivesMatter, and using Black autoethnography, Black hashtagging, Black intercontextual reading, and reimagined Black disruption, Maraj focuses on the temporal components of time, space, and place to examine how campus and community members are demonstrating that diversity is racial. In this text, he boldly reveals the impact this work has on Black bodies often at the center of these practices. Finally, Maraj hopes this book will serve the Black community by telling its stories, help to rewrite the white academy's master and expired narratives, and create space for non-Black audiences to recognize why this work [always] matters/ed. He is writing this for us and them. To support these ambitious goals, the book is organized into four chapters, including a very imaginative preface that gives us insight into Maraj's Black Caribbean background, an introduction that methodically outlines the scope and objectives of the text, and a conclusion that makes you snap your fingers while saying, "Yasss!" [slang term in the Black community that is used out of excitement; a more vibrant form of yes].

Creatively, all section titles contain familiar phrases prevalent in the Black/Black Caribbean culture, making the reader appreciative of Maraj's intentionality and ability to bring his full self to this work. Unlike typical preface sections in books, Maraj uses this space to uniquely greet his readers by writing six different renditions of essentially the same message. Reflecting the true nature of a rhetorician and writing studies scholar, he plays around with language, subtly providing a counterstory of how Black folx tell and write their stories in formal, public spaces and how we often feel like we have to code switch or renegotiate how we show up depending on the audience. Counterstories are stories [not often] told by marginalized groups to reimagine/disrupt/interrogate the master narratives that exist about them. These master narratives are told from those at the top [usually white folx] who are trying to maintain their power and corroborate their place as superior (Delgado, 1989). Maraj's use of counterstories, exhibited throughout this book, provides comfort to the reader who may be carrying traumatic writing and expressive experiences. His words provide hope and he dares his audience to take ownership of their vernacular and have the audacity to just $b e$. The preface makes clear he is being deliberate in his selected writing style, utilizing his native tongue to reveal his intersecting identities and making space for Black folx to feel welcomed within his words. Maraj confirms from the very beginning that it's okay to let our hair down, to kick off our shoes and dive in. He is decolonizing ways of believing and being in writing classrooms and in academia. This narrative is completely contradictory to the white academy that strives to assimilate us by forcing us to write, express ourselves, and navigate its systems in a very specific way. When sharing details about the first C- he received on his English paper in college, Maraj writes,

The lavish prose I was brought up on in the British Caribbean education system wouldn't work here. Americans want a thesis. Panicked by the high grade point average I need to continue holding my scholarship, to stay in the country, I adjust quickly and finish the course with a low $A$. Assimilative conversion, then, becomes my recourse. (p. 4)

Maraj allows us to readjust, reclaim, and rewrite-and it is quite refreshing. My favorite (and the last shared) rendition of his greeting in the preface, acknowledges that the five preceding versions may have been confusing to the reader. Yes, they were, and this confusion is freeing because Maraj takes ownership of the space 
he has created, and he doesn't care if you get it or not. Black folx are forced to assimilate every day, and here, Maraj says nah [no]:

\section{Word Readers,}

You might be confused. Embrace It. Or don't. Blackness often obfuscates [confuses], often disorients, often shatters/ scatters fungibility but offers much by way of meaning. Take care. That is to say, like poetry, the artful craft of de ting lies in being okay with not knowing in order to not know.

\section{So leh we mash up de place together, nah?}

\section{Later,}

\section{Louis M. Maraj}

Black or Right's introduction lays out the foundation for the book by providing its ontological perspective of how it came to be and what brought Maraj here. Maraj eloquently begins this section by sharing parts of his own story as a Black Caribbean immigrant who came to the United States in hopes of achieving the "American Dream." Throughout this text, I stood in solidarity with Maraj, giving fist pumps and head nods, knowing other Black folx would also see themselves in his many personal accounts. His stories aren't necessarily unique, but they aren't told enough. Interdisciplinary in nature, Maraj's text connects Black studies and Critical Race Theory (CRT) to rhetoric, writing, and literary studies. As he intimately shares many of his own lived experiences, he draws on Black feminist approaches, particularly Black feminist thought, and African Indigenous methodological approaches. Leaning on several academic disciplines [such as sociology, history, political science, women's, gender, and sexuality studies, digital media studies, criminal justice, postcolonial studies, historiography, and others], Black or Right confirms that Black folx are dynamic, with intersecting ways of being, doing, and living, and thus show up in multiple ways on predominantly white campuses.

One of the things readers will immediately notice, and what I found to be one of the most invigorating features of this text, is Maraj's commitment to honor Black scholars, who are characteristically excluded from citations, reading lists, and curriculums, while speaking about the foundation and methodology of his research. The first time I read a book by a Black scholar in the classroom was in college, and I am convinced that was only because I minored in African American studies. I only read those texts in those classes. Therefore, it matters that Maraj and other Black authors are intentional about highlighting the work of those who look like us. Long gone are the days when we only read about Black folx in Black classes, in Black spaces, in the footnotes, during Black History Month. Also, we've had enough of the same old and tired slave/ struggle narratives. Black or Right pays homage to and educates readers on the Black academy's social justice pioneers, whose trailblazing paths and research encourage us to keep running in this race and reminds us we are dynamic. Courageously accepting the baton to complete the next leg, Maraj empowers and pushes us to run alongside him through his creative ability to discuss these topics through literary events, discussions, and assignments he has created in his own safe space of a classroom.

Chapter 1 purposely utilizes autoethnography to confirm that Black folks are storytellers and that sharing these stories, particularly in anti-Black spaces, matters. Our shared intimate accounts can be the catalyst of critical conversations. Maraj relates his experiences as a Black graduate student and instructor to the reader. He shares stories of being racially profiled and the center of a university's "diversity" marketing campaign. How many Black folx were on their institution's website or "encouraged" to get in the picture because they were Black? Raises hand. For every story Maraj shared, for better or worse, I had an equivalent one. A particularly interesting story he shared in this chapter was from the time he taught at a predominately white institution (PWI). One of his Black students repeatedly questioned whether Maraj was Black. While this eventually annoyed Maraj, what I found most compelling is how Maraj admits to equally stereotyping the student. Maraj expresses,

Like Vershawn Young, in his article, "Your Average Nigga" (2004) and a subsequent monograph by the same name (2007), I stereotyped T based on his clothes, demeanor, and language. And while my initial reaction to $T$ was optimistic, as opposed to Young's reaction to his "ghetto" student Cam. . .that impression does not make my profiling any less harmful. (p. 30)

This narrative brought me back to my earlier "judgey" questions of texts written by my fellow Black scholars. Maraj's account confirms I'm not alone in this [but I still feel guilty]. It confirms that if we aren't careful, these white systems will allow us to sell ourselves and our brothers and sisters short. It also made me reflect on a counterexperience I had while teaching at Coppin State University, an $\mathrm{HBCU}$ in Baltimore City, Maryland. My teaching experiences at PWIs compared to HBCUs or predominantly Black spaces are like night and day. On the first day of class, the students at Coppin were elated when I entered the room and even roared when I told them I was pursuing my $\mathrm{PhD}$. They felt honored that someone who looked like them was leading them to success, and they routinely celebrated me. The first question posed to me was, "What makes you keep going?" I knew at that moment that I was in for a treat, and I was right. This has been my best teaching experience to date.

I further reflect on the recent and public controversy around Pulitzer Prize-winning Black journalist Nikole Hannah-Jones, who was recruited by one of the top PWIs in the nation, UNC, in Chapel Hill, North Carolina, this summer. She was refused tenure [based on the vote of a white man] and then awarded tenure following a public outcry. In the spirit of going where you are celebrated, she 
declined the position at UNC and accepted a lucrative offer at one of the top HBCUs in the country, Howard University, in Washington, DC. This same spirit is reflected through Maraj's words. Maraj doesn't just merely tell us stories, he brilliantly reveals the tangled web many white institutions create for Black folx who just want to be unapologetically Black. He shows why we go where we are celebrated. By utilizing Black autoethnography, he demonstrates how this method can be a rhetorical tool to confront/resist antiracist practices in white spaces, places, and contexts. Our stories matter and who contributes to/benefits from them matters too.

Chapter 2 does a phenomenal job in highlighting the research of Black digital and social media scholars and connecting what is traditionally seen in those disciplines to sociolinguistics and writing composition. Specifically, he discusses ways Black cultural hashtags and literacy events can facilitate conversations on race and Blackness and create resistance on white campuses. Many institutions have implemented diversity and inclusion-based courses and/or assignments in their general education requirements. This is an opportunity for Black faculty members in particular to thrive by being able to create nontraditional, innovative, and transformative syllabi that may not normally be offered in their respective departments or on their campuses. Maraj, in great detail, discusses a semester-long assignment he created for one of his classes called the "Tumblr Commonplace Book," which meets his university's general education social change requirement (Maraj, p. 58). Maraj's overview of this assignment can serve as a tangible resource for faculty who wish to add more tools to their toolkit and integrate critical thinking work into their curriculum. Through "marginalized literacy," a term Maraj coined to describe how utilizing hashtags is a literacy practice of oppressed communities striving for social justice, the Tumblr Commonplace Book allows students to intellectualize and create their own hashtags as counterspaces to analyze messages on and make meaning of Black resistance and activism, particularly in a predominately white classroom setting. He then provides a quasi-narrative analysis of the students' work by focusing on shared themes and associations in a very intriguing way. I highlight this particular assignment because faculty who teach social justice-based courses are extremely important, especially when these classes are composed of mostly white students, as they provide a rich opportunity for white students to engage in topics they probably would not normally engage in.

A possible limitation of chapter 2, however, a chapter that could have contributed significantly to one of the book's goals of showing how multiple meanings of Blackness are being played out in the classroom, is not discussing the impact that these types of assignments have on the very few Black students in the class. I wonder if these types of assignments could be unsubtle or unintentional acts of oppression, exploitation, and tokenization too? In the cited academic year, out of 41 students from both semesters, only 5 of Maraj's students identified as Black. While I am a Black faculty member, I am also a Black graduate student in a mostly white space. I can attest that these types of assignments and conversations do impact Black students. Specifically, it can feel like our Black professors-which can feel like another [exhausting] role in Black performativity.

Chapters 3 and 4 ask readers to think broadly about what Blackness means and the visual/material/literary representations of it in the era of "post-Ferguson"/\#BlackLivesMatter by providing readers with an analysis of popular Black cultural texts, songs, and other media artifacts situated around this time. Unique to chapter 3 and this text is Maraj's attention to Black women and the daily struggles we face in having to always figure out who we are going to be and how we are going to show up in different spaces, as is also reflected in my opening story. For example, he makes rhetorical connections among Beyonce's Lemonade, religion/spirituality, politics, and history, further illuminating how Blackness is truly interdisciplinary and intercontextual and should be discussed in all spaces, all classrooms, on all campuses (Maraj, p. 98). These chapters examine the overt and implied ways white institutions are cocreating racial meaning through language, and the defensiveness often extant when they are confronted about these messages. Maraj powerfully offers various contexts for connections to be made, including those that are not always addressed such as bodies, intersecting identities, movements, and systems that coconstruct multiple meanings.

This chapter calls out/in the [often ambiguous] words many white institutions use in their "diversity" statements and how Blackness is exhibited (or not) within them. A possible missed opportunity in this chapter is diving into the impact these often-vague diversity statements/rhetorical fallacies have on Black students, faculty, and staff. Sharing these stories could provide a teaching moment to those crafting these statements, identifying why language, intention, and impact differ/matter. Maraj even quotes the US Census Bureau (Maraj, p. 80) in the vague way they describe "Black" and "race," reemphasizing that the obscurity created by society surrounding Blackness goes beyond campus institutions. Chapter 4 confronts white institutions about re/examining why, how, and what they really mean when they use the \#BlackLivesMatter hashtag. Are they making it a temporal moment or movement? Chapter 4 further challenges white institutions to replace being on the defensive with feeling hopeful about answering, Whose responsibility is it to make our Black community feel like their lives matter here, and what are we purposefully and creatively doing about it [every day] to live up to it?

The final chapter brings together the goals and literacy events of each previous chapter. Through these rhetorical reclamations, solutions are provided for how white institutions can avoid racist practices and eliminate actions signifying defensiveness-a pattern that ultimately stagnates, limits, and minimizes potential for the transformative change needed on these campuses. Maraj ends the text by reminding both the insider and outsider of the importance of acknowledging, writing, telling, and listening to the stories of what it means to be Black. My own research utilizes 
the interpersonal communication theory, retrospective storytelling, which posits that the stories we hear and tell can have a lasting impact on our identity, relationships, and health or well-being (Flood-Grady \& Koenig Kellas, 2019). Thus, I further challenge readers [of all backgrounds] to consider what happens after the story is written, told, and listened to? How are these stories affecting our identities, our relationships, and our well-being, and how are we collaboratively coming together after telling and listening to these stories to create real change?

At the conclusion of this book, I thought back to my "judgey" questions upon starting the text: "Will this come off as another inner protest piece with heavy jargon and incomprehensible ideas to prove this Black author is smart and belongs here too? Sis/Brother, who are you really writing this for-us or them?" I keep revisiting this and am intentionally labeling these thoughts as judgey because the implications are important. We must start naming the truth, even when it hurts - especially in academia. I made some discoveries because of this book about why these judgey thoughts make me feel bad. Let me make the connection clear. I don't ask these same questions going into the reading of texts written by non-Black, white scholars, and I wonder if it's because I have been so conditioned in these racist school systems to assume that white is right? Ugh. What other ways have I been conditioned? I reflect on Maraj's goals of writing Black or Right and see clearly why this text is so necessary and timely, and how even as a pro-Black person used to operating in white spaces, so much of my mental/ public/academic narrative still must be unlearned and rewritten. This white institutional conditioning even has Black people questioning other Black people. We are used to our papers being slashed with red pens. We are used to being the only Black person on our university's homepage. We are used to being the Black voice in our white classrooms. We are used to being told we were "nominated" to serve on the diversity and inclusion committee. We are used to being questioned and critiqued about messages surrounding Blackness. We are used to being the spokesperson whenever something racial happens. Stop using us.

Does this book achieve its goals? I would say that my countless finger snaps, yelled "Yaaaaaasss Maraj?", fist pumps thrown in the air, and a renewed commitment to prioritize my community [and myself] as a Black scholar, as a result of reading this text, mean a resounding YES! You brought your whole self, multiple identities, and diverse lived experiences to this text, dear brother Maraj, in the spirit of your mother who allowed you to leave the islands to come to the US for greater opportunities - this book is a manifestation of her knowing your worth. Thank you for writing this fascinating piece that reminds us to never forget our worth, to demand our respect, and for educating and engaging all people in this necessary dialogue.

\section{Black is right. Black is right. Black is right.}

When you know you are of worth,

you don't have to raise your voice,

you don't have to become rude,

you don't have to become vulgar; you just are.

And you are like the sky is, as the air is,

the same way water is wet.

It doesn't have to protest.

-Dr. Maya Angelou

But Black folx are always protesting.

Dear Brothers and Sisters, never forget: We always mattered. We always will.

\section{References}

Delgado, Richard. (1989). Storytelling for oppositionists and others: A plea for narrative." Michigan Law Review, 93(1), 2411-2441.

Flood-Grady, Elizabeth, \& Koenig Kellas, Jody. (2019) Sensemaking, socialization, and stigma: Exploring narratives told in families about mental illness, Health Communication, 34(6), 607-617.

Maraj, Louis M. (2020). Black or right: Anti/racist campus rhetorics. Utah State University Press.

Kendi, Ibram. (2019). How to be an antiracist. Bodley Head.

\section{Acknowledgements}

Mom and Dad, you are the epitome of dope. I am the luckiest gal in the world to have you as my parents and my biggest fans. Not only do I love you [unconditionally], but I also genuinely like you. I am only here and who I am today because of you + God. To the moon, love you more.

To Aunt Dr. J and my Jameson family, you are one of my greatest blessings. You're stuck with me forever.

To Dr. Shannon Madden, thank you for always making room for me at the table and for being an anchor, cheerleader and friend during this doctoral journey. Thank you for always reminding me of my worth. 